Commonwealth of Massachusetts

Department of Public irorks

ii. F. Callahan, Comrissioner
U. S. Lepartment of the Interior Geological Surrey

ii. E. irather, Director

[ns.10/] Cooperative Geologio Project

Geologic Interpretation of Seismic Dete

Route 128 (Northern Circumferential Highway)

Cut, and Hopkins Streot Grade Separation

Stations 1-18

in ivakefield, Lass.

by

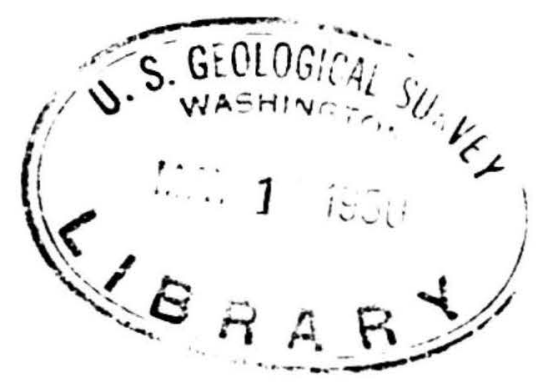

James E. Maynard, Geol ogist, U. S. Geological Survey

and

Rev. Daniel Linehan, S. J., Seismologist, heston College

\pm pages of text

3 plates $\checkmark$

U S GEOLOGICAL SURVEY

DEPT OF PUI-1C WJRKS OPEN FILE REPORT

wi this report have been placed in op n files for publi. insir.tius at -IINGON, D.C., GENERAL SERVICE-BLD' , F at 18th d loth - Y. IV. C.S. GFOLOCICAL SUIRITY LIBRARY, and office of the i t.INIRRING GEOI.OGY BRANCH

MASACHUSETTS, 100 NASHIA ST. Offices of the PROJECT


?i- - 
Geologic Interpretation of Seisuic Data

Route 128 (iNortinern Circumferential Highway)

Cut, and Hopkins Street Grade Separation

Stations 1-18

in irakefield, Niass.

Dy

James E. Liaynard, Geologist, J. S. Geological Survey

and

Rev. Daniel Linehan, S. J., Seismologist, iest on College

\section{General Statement}

The completion of a segment of the Northern Circumferential Highway, Route 128, in Viakefield, Masse, requires an underpass bridge at Fopkins Street, Staticn 5+50. The rlan of the project shows approximately 1800 feot of approach cuts jetween stations 1 and 18. In October 1945 a prelininary seismic study was made of a sezment of this cut between stations $6+50$ and 13+jo. Four profiles were made at this time and a report was submitted by Newt on E. Chute and Rev. Daniel Linehan (file report of Jenuary 15). This work showed a relatively shellow (in general, 6 to 12 feot in depth) somewhat irregular bedrock surface between stations $6+50$ and $13+50$. That data indicated thet much of this segment of the cut will be in bedrock. In order to obtain more complete data for the preparation of detalled estimates on the amount of bedrock to be excavated for this segment of the cut, and also to obtain sufficient date for the unexplored segment of the cut, 21 additional seismic traverses were made in September 1949. The present report contains only the results obtained from this later work. 
Thy work was performed as a part of a cooperative program of the Massachusetts Department of Public Vorks and the Jnited States Geological survey •

\section{Surface Geology}

At this location the proposed road will traverse the southeast side of a large bedrook-till hill that is flanked by a sand-eravel kame terrace. The poorly defined boundary, of the terrace and the till area crosses the proposed center 1 line in the vicinity of station 5+70. Numerous outcrops of bedrock occur within 200 feet of the centerfine; they are comosed of somewhat coarse grained, slightly pink granite, medium-grained dark-colored melanite, or a combination of both of these types of rock. Inese rocks appear to underlie the entire area of the proposed cut. The till as observed in shallow test pits is loose to moderately loose in texture; in most places it is covered by a layer of fine sand fram a few inches to 3 feet in thickness. The surface Eeology of the site and of the adjacent surrounding area sugsests that the till is a rather thin veneer on an irregular bedrok surface. A toofogio-maptith the locetions of the center-line and the seisnic traverses is shown on sheet 1 . $=$

\section{Soismic Iraverses}

The layout of the seismic traverses is snown on the geologic map, she日t 1. ine lengths, in feet, of the seismic traverses are as follows:

$$
\begin{array}{ll}
A^{\prime}-B^{\prime}, & 165 \\
B^{\prime}-C^{\prime}, & 165 \\
A^{\prime}-D^{\prime}, & 110 \\
E^{\prime}-P^{\prime}, & 150 \\
E^{\prime}-I^{\prime}, & 165 \\
G^{\prime}-H^{\prime}, & 165 \\
H^{\prime}-J^{\prime}, & 180
\end{array}
$$

$\begin{array}{ll}K^{\prime}-L^{\prime}, & 165 \\ N-O, & 220 \\ P-Q, & 220 \\ K^{\prime}-2, & 220 \\ A-B, & 220 \\ B-C, & 220 \\ C-D, & 220\end{array}$

$\mathrm{D}-\mathrm{Q}, \quad 220$

$F-G, \quad 220$

G-H, 220

$\mathrm{H}-\mathrm{I}, \quad 220$

I-J, 220

K-I, $\quad 165$

L-if, 220 
The shot points for the seismic traverses were located as follows:

\begin{tabular}{|c|c|c|c|c|c|c|c|c|c|c|c|}
\hline $\begin{array}{l}A^{\prime}, \\
B^{\prime}, \\
C^{\prime},\end{array}$ & stat & tion & $\begin{array}{l}5+30 \\
3+65 \\
2+00\end{array}$ & & & & & & & & \\
\hline$D^{\prime}$, & 108 & feet & to & the & left & (north) & of & station & $5+08$ & - & \\
\hline$E^{\prime}$, & 50 & $"$ & $n$ & $n$ & $n$ & n & $n$ & $n$ & $5+38$ & & \\
\hline$F^{\prime}$, & 50 & n & " & $n$ & n & $"$ & $n$ & " & $3+88$ & & \\
\hline$I^{\prime}$, & 50 & $n$ & $*$ & $n$ & $n$ & $n$ & 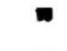 & $n$ & $2+23$ & & \\
\hline$G^{\prime}$, & 50 & $n$ & $n$ & $n$ & rizht & (south) & $\varpi$ & 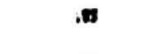 & $5+30$ & & \\
\hline $\mathrm{H}^{\prime}$, & 25 & n & $"$ & $n$ & n & " & " & $"$ & $3+65$ & & \\
\hline J', & 55 & $"$ & $n$ & " & $n$ & $n$ & $n$ & n & $1+85$ & & \\
\hline $\mathrm{K}^{\prime}$, & ste & ation & $5+9$ & & & & & & & & \\
\hline Li, & 15 & n & $"$ & $"$ & $n$ & $\left(S \bullet E_{\bullet}\right)$ & $n$ & n & $8+14$ & & . \\
\hline N, & 50 & n & $"$ & $n$ & $n$ & $"$ & $n$ & $"$ & $6+07$ & & \\
\hline 0 & 55 & $n$ & " & $n$ & " & " & $n$ & $n$ & $8+20$ & & \\
\hline$P$, & 50 & $n$ & $n$ & " & left & (N.H. & " & " & $5+82$ & & \\
\hline Q, & 54 & " & n & $n$ & & " & " & $n$ & $8+14$ & & \\
\hline A, & 32 & " & $"$ & $n$ & n & $n$ & $\mathbf{n}$ & $n$ & $17+20$ & & \\
\hline B, & 53 & $"$ & n & n & " & $n$ & $n$ & $n$ & $15+00$ & & \\
\hline$C$, & 57 & $n$ & $"$ & $n$ & $n$ & " & " & $n$ & $12+80$ & & \\
\hline D, & 55 & $"$ & $"$ & $n$ & $n$ & $n$ & $n$ & $n$ & $10+40$ & & \\
\hline$F$, & ste & $\begin{array}{l}\text { ation } \\
\text { " }\end{array}$ & $17+$ & ח & & & & & & & \\
\hline$G$, & & & & & & & "1 & " & & & \\
\hline $\mathrm{H}$, & 15 & $\begin{array}{c}\text { feet } \\
\text { " }\end{array}$ & $\begin{array}{l}\text { to } \\
\text { " }\end{array}$ & $\begin{array}{l}\text { the } \\
\text { " }\end{array}$ & $\underset{n}{\text { right }}$ & $\underset{n}{(S \bullet E \bullet)}$ & $"$ & $"$ & $12+58$ & & \\
\hline I, & 18 & $"$ & 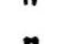 & n & " & $n$ & $n$ & $"$ & $10+20$ & & \\
\hline $\mathrm{J}$, & 4 & $"$ & $n$ & $n$ & 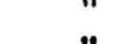 & . & 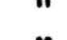 & $"$ & $8+22$ & & \\
\hline $\mathrm{X}$, & 42 & $"$ & $"$ & $"$ & $"$ & n & $"$ & " & $11+88$ & & \\
\hline L, & 63 & " & 18: & $n$ & " & " & $n$ & " & $10+26$ & & \\
\hline
\end{tabular}

\section{Depths to Bedrock}

The depths to bedrock at the shot points as calculated from the seismic data are as follows:




The geologic sections as interpreted from the seismic data, and the geology of the site are shown on sheets 1,2 , and 3 . Although the bedrock surfaces are shown by smooth curves in the sections, it is probable that the actual bedrock surface is much more irregular than these curves suegest, as the detectors were too widely spaced to pick up very small ricies and points. The positions of the bedrock surfaces in the vicinity of shot points $B^{\prime}, F^{\prime}$, $C$, and $b$ may be closer to the surface and may differ appreciably in configuration from these forms shown on the sections. Wuch of the difficulty in interpretation at these places may have been caused by the refistration of side refractions instead of vertical refractions when shooting in opposite directions froin common shot points. The most logical interpretation from the available seisnic data and the geology is shown by the dotted lines. The actial depths to bedrock at shot points A', J', C, A, K, K', 0 , and $N$ may vary a foot or more from the reported value, for they were calculated from assumed, though reliable, till velocities determined from nearby traverses. The depth to bedrock at shot point $F$ was similarly calculated because the two detectors nearest the shot point failed to register; this value also should be of ressonable accuracy. 


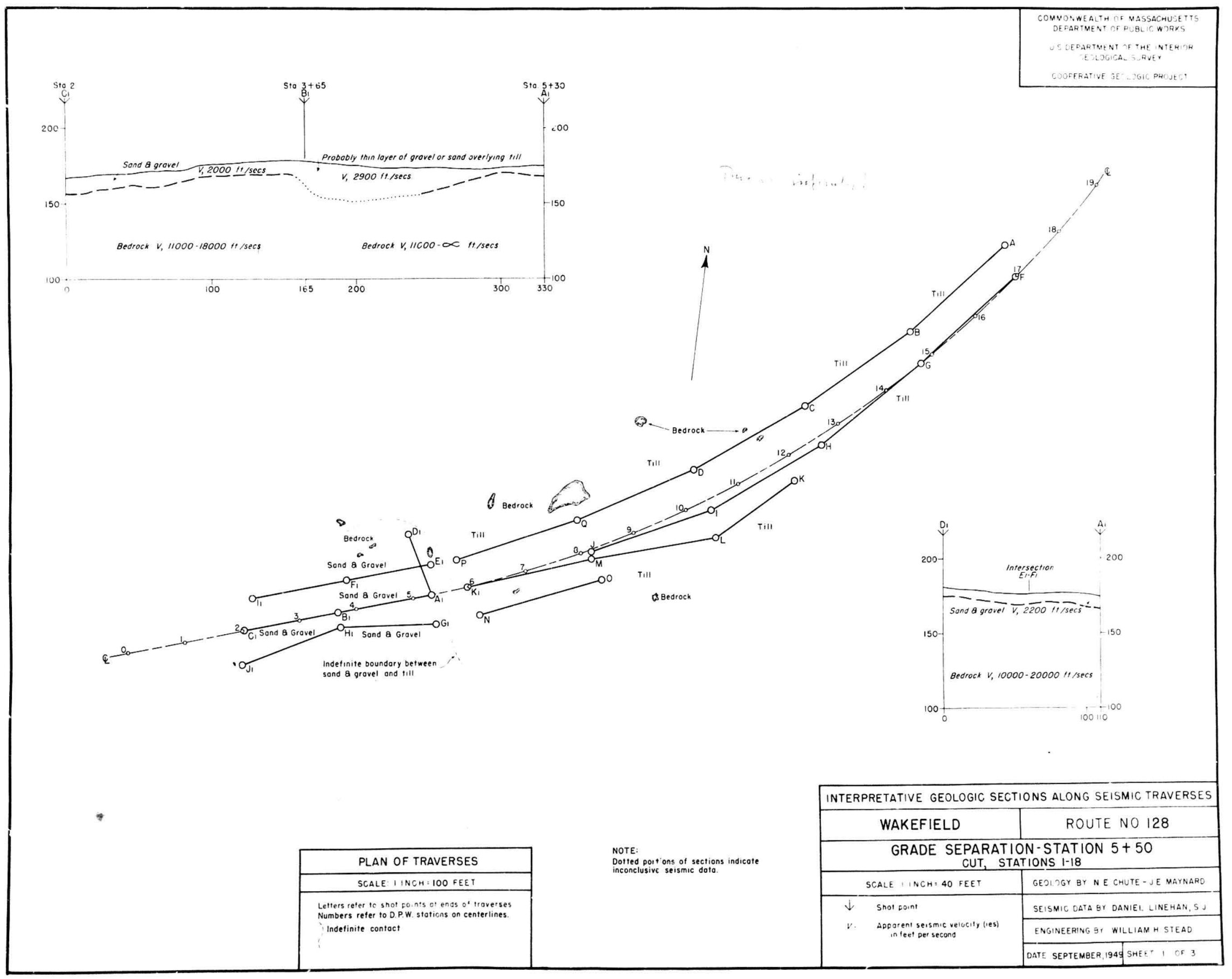




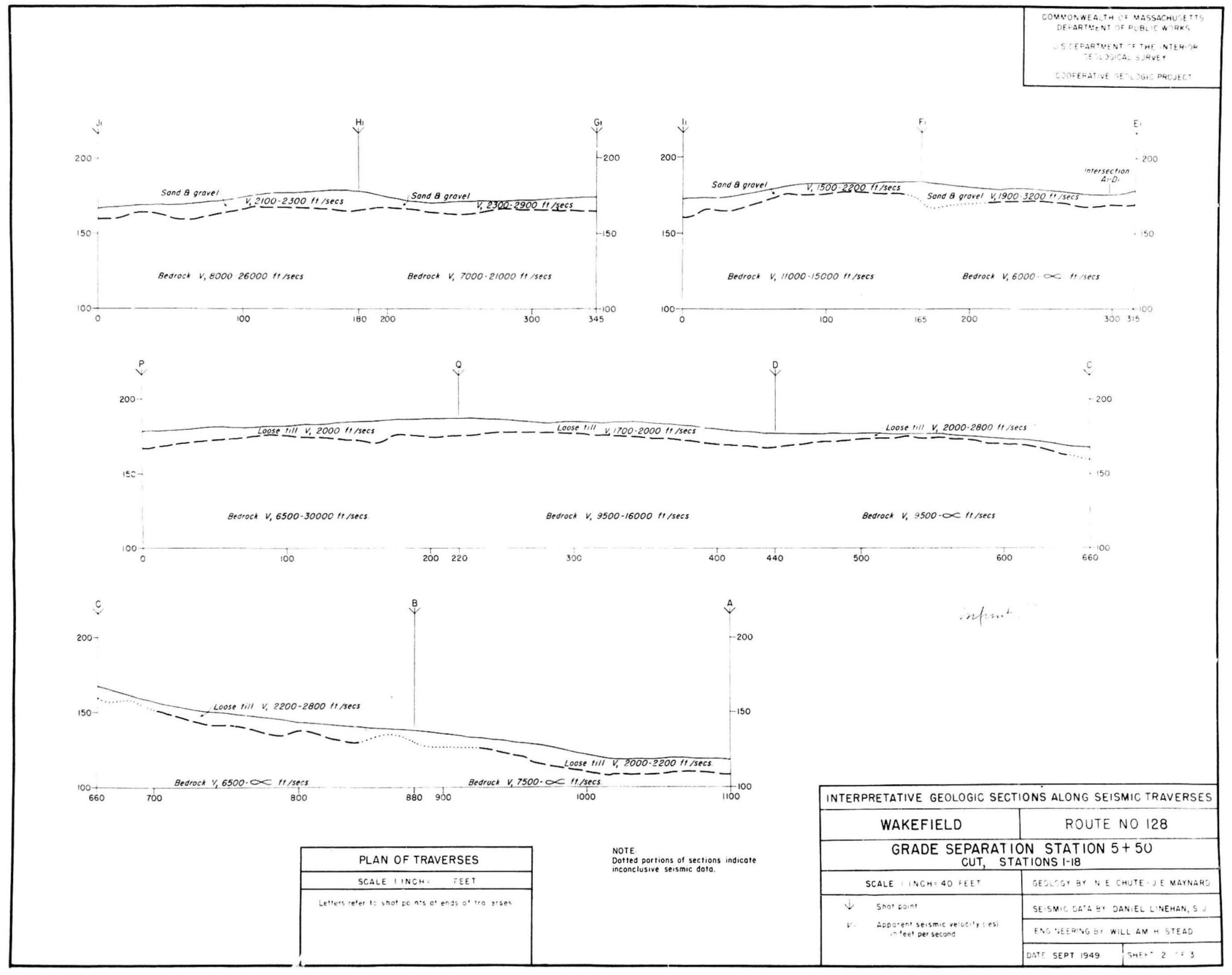




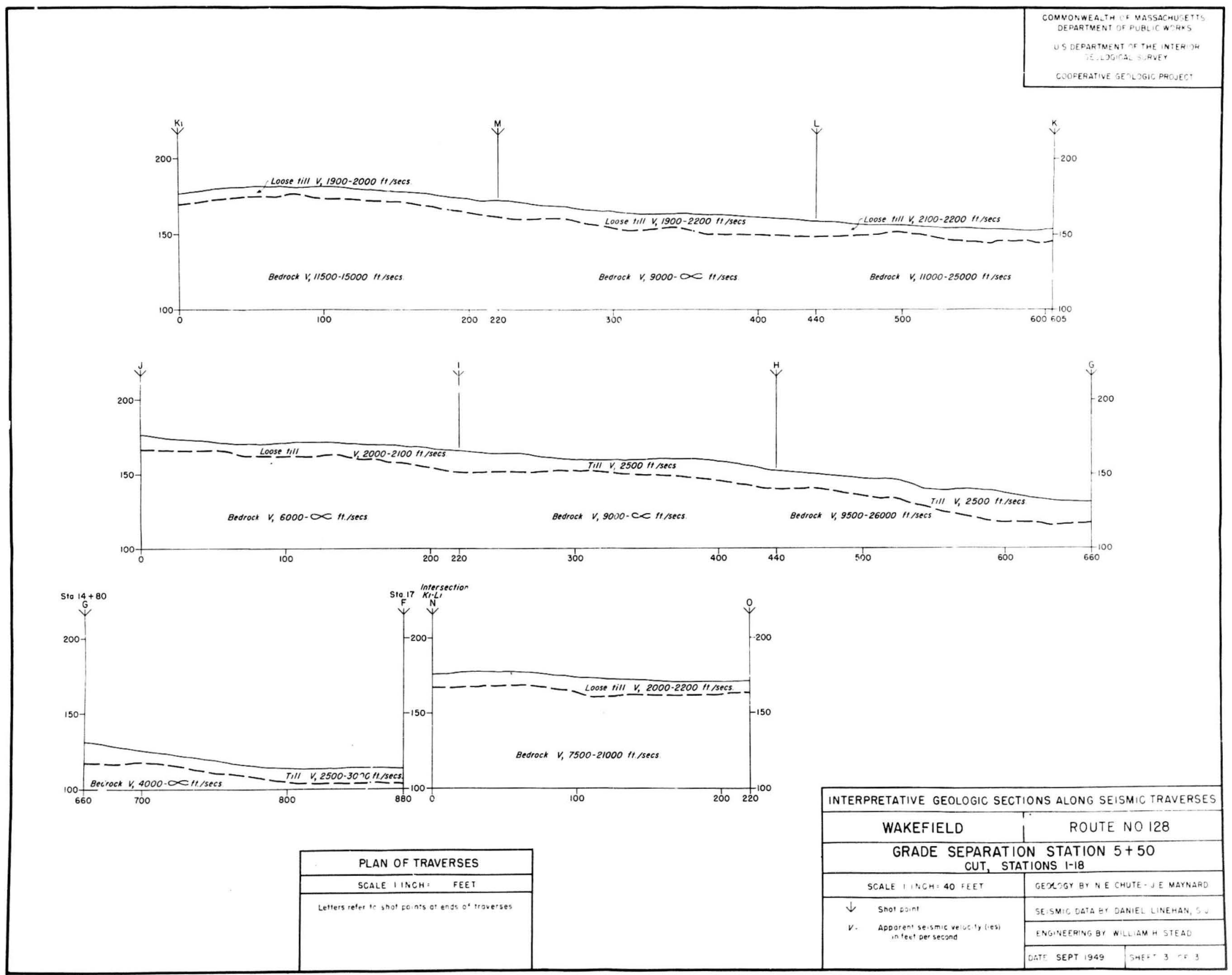

